\title{
Wind Power Potentials in Cameroon and Nigeria: Lessons from South Africa
}

\author{
Abdullahi Abubakar Mas'ud 1,*, Asan Vernyuy Wirba ${ }^{2}$, Jorge Alfredo Ardila-Rey ${ }^{3}$, \\ Ricardo Albarracín ${ }^{4}$, Firdaus Muhammad-Sukki ${ }^{5}$, Álvaro Jaramillo Duque ${ }^{6}$, Nurul Aini Bani ${ }^{7}$ \\ and Abu Bakar Munir 8,9
}

1 Department of Electrical and Electronics Engineering, Jubail Industrial College, P.O. Box 10099, Jubail Industrial City 31261, Saudi Arabia

2 Department of Management and Information Technology, Jubail Industrial College, P.O. Box 10099, Jubail Industrial City 31261, Saudi Arabia; asan_v@jic.edu.sa

3 Department of Electrical Engineering, Universidad Técnica Federico Santa María, Santiago de Chile 8940000, Chile; jorge.ardila@usm.cl

4 Department of Electrical, Electronic and Automation Engineering and Applied Physics, Senior Technical School of Engineering and Industrial Design (ETSIDI), Polytechnic University of Madrid (UPM), Ronda de Valencia 3, 28012 Madrid, Spain; rasbarracin@gmail.com

5 School of Engineering, Robert Gordon University, Aberdeen AB10 7GJ, UK; f.b.muhammad-sukki@rgu.ac.uk

6 Department of Electrical Engineering, Universidad de Antioquia, Cl. 67 \#53 - 108, 050010 Medellín, Antioquia, Colombia; alvaro.jaramillod@udea.edu.co

7 UTM Razak School of Engineering and Advanced Technology, Universiti Teknologi Malaysia, Kuala Lumpur 54100, Malaysia; nurulaini.kl@utm.my

8 Faculty of Law, University of Malaya, Kuala Lumpur 50603, Malaysia; abmunir@um.edu.my

9 University of Malaya Malaysian Centre of Regulatory Studies (UMCoRS), Level 13, Wisma R\&D, University of Malaya, 59990 Jalan Pantai Baru, Kuala Lumpur 50000, Malaysia

* Correspondence: abdullahi.masud@gmail.com; Tel.: +96-653-813-8814

Academic Editor: Lieven Vandevelde

Received: 23 February 2017; Accepted: 21 March 2017; Published: 27 March 2017

\begin{abstract}
Wind energy has seen a tremendous growth for electricity generation worldwide and reached 456 GW by the end of June 2016. According to the World Wind Energy Association, global wind power will reach $500 \mathrm{GW}$ by the end of 2016. Africa is a continent that possesses huge under-utilized wind potentials. Some African countries, e.g., Morocco, Egypt, Tunisia and South Africa, have already adopted wind as an alternative power generation source in their energy mix. Among these countries, South Africa has invested heavily in wind energy with operational wind farms supplying up to 26,000 GWh annually to the national grid. However, two African countries, i.e., Cameroon and Nigeria, have vast potentials, but currently are lagging behind in wind energy development. For Nigeria, there is slow implementation of renewable energy policy, with no visible operational wind farms; while Cameroon does not have any policy plan for wind power. These issues are severely hindering both direct foreign and local investments into the electricity sector. Cameroon and Nigeria have huge wind energy potentials with similar climatic conditions and can benefit greatly from the huge success recorded in South Africa in terms of policy implementation, research, development and technical considerations. Therefore, this paper reviews the wind energy potentials, policies and future renewable energy road-maps in Cameroon and Nigeria and identifies their strength and weakness, as well as providing necessary actions for future improvement that South Africa has already adopted.
\end{abstract}

Keywords: renewable energy; wind power; Cameroon; Nigeria; South Africa 


\section{Introduction}

Due to the world technological advancement and rise in population, energy has become an important unit for the dwellers of the global village. Sadly, in this current era, some developing countries in the world are short of electricity supply due to the increase in energy demand. Currently, in most parts of the world, fossil fuels and other non-renewable energies have been the primary power sources, but recent investigation shows that they are depleting rapidly [1]. There is the problem of pollution with non-renewable sources with serious environmental and health effects. These challenges bring about the need for renewables in the future energy mix of many countries in the world.

By the end of 2015, renewables comprised approximately $23.7 \%$ of the global electricity generation (see Figure 1), with hydro-power supplying up to 16.6\% [2]. Though there are high renewable energy (RE) potentials globally and the share of renewables in world electricity production is growing, it is still insignificant compared with the conventional sources. Currently, most renewable additions vary from country to country coupled with the increase in electricity demand [2]. Among these renewables, wind technologies supply just about $3.7 \%$ of world electricity production [2,3].

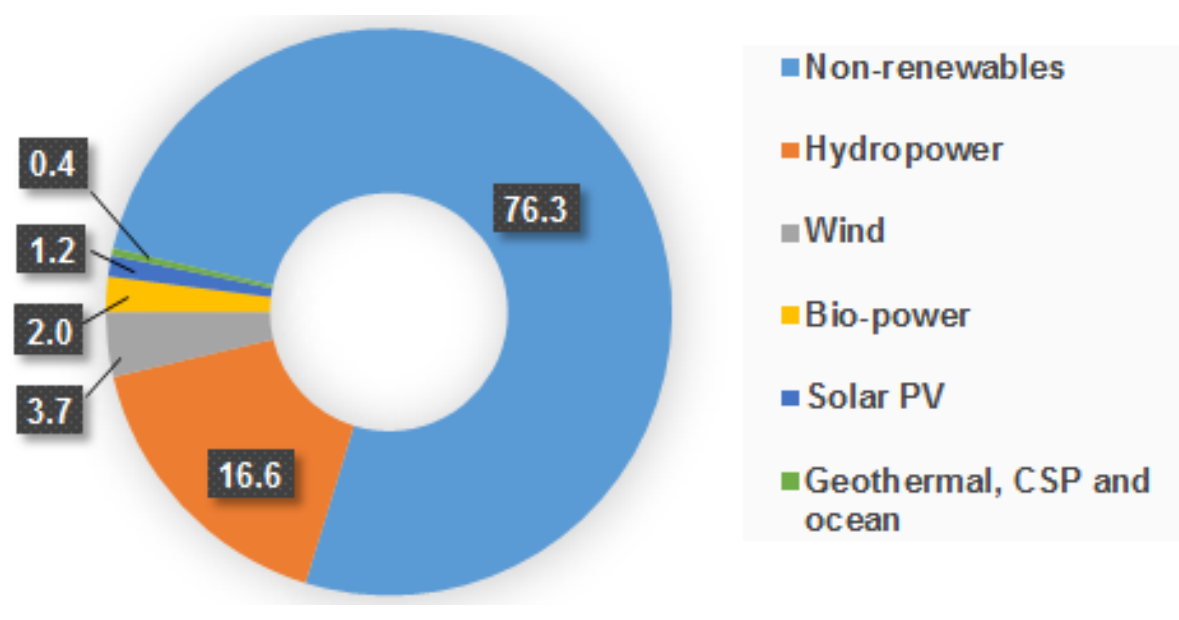

Figure 1. An estimate of RE in world power production, 2015. Adapted from [2].

There are several advantages of wind power, which are [4]: easy to tap; easier installation of the wind turbines when compared with others (e.g., hydro turbine technologies or marine technologies) regarding space allocation and installation time; flexibility of locating wind farms, i.e., onshore and offshore, among others. Despite the advantages of wind power, there are concerns regarding its negative social and environmental impacts [5] and about large-scale infrastructural development that requires proper understanding [6]. There are observed effects of such impacts on landscaping, noise generation, disputes with communities and land use issues [2,5]. Though the cost of wind generation has fallen rapidly over the last decade, the public financial support for wind energy continued decreasing and hinders the development of several wind farms projects globally [3]. Despite all of these issues, wind power is still more applicable and profitable compared to other renewable energies and, in some cases, competitive with traditional sources.

The world installed wind capacity rose to $456 \mathrm{MW}$ in 2016 and will reach $500 \mathrm{GW}$ by the end of the year, as illustrated in Figure 2 [7]. This is an indication that wind power markets are still active. At the end of 2015, Europe has installed wind power capacity of 147,771 MW, Africa and the Middle East 3289 MW, North America 88,744 MW, Latin America and the Caribbean 12,220 MW, Asia 175,573 MW and the Pacific region 432,419 MW [3]. Asia has the highest growth capacity, while Africa and the Middle East have the lowest growth capacity at the end of 2015 [3]. Despite high wind potential in Africa [8], there is a significant gap between the potential and the level of implementation. This raises grave concern regarding the development of wind farms projects in the continent. 


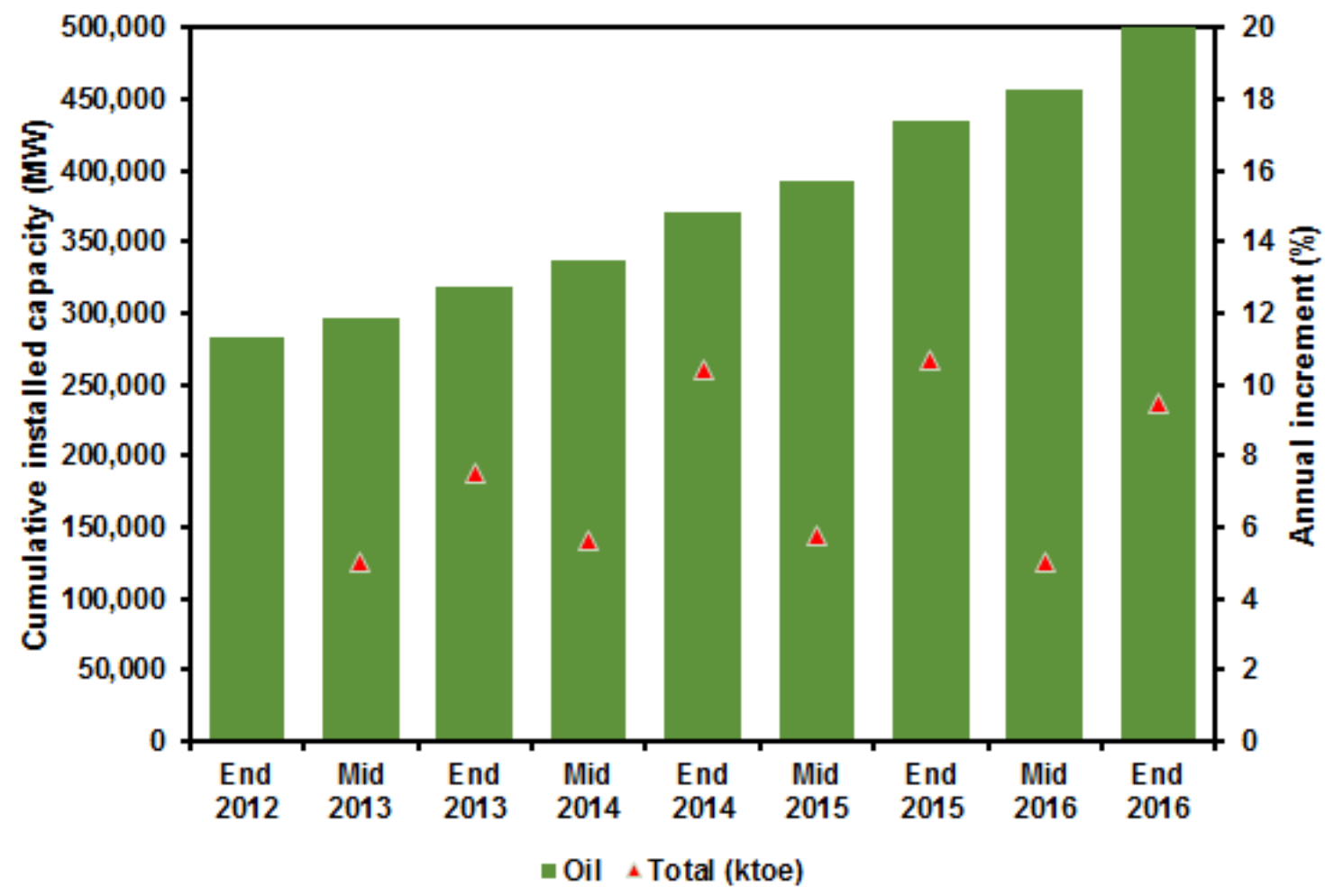

Figure 2. Total installed capacity in the world 2012-2016 in MW. Adapted from [7].

All wind turbines installed worldwide by June of 2016 can generate around 4.7\% of the world's electricity. The top 10 new installed capacity by country in 2016 is presented in Table 1 [7].

Table 1. The top 10 new installed capacity by country in 2016 [7].

\begin{tabular}{cc}
\hline Country & Installed Capacity \\
\hline China & $10 \mathrm{GW}$ \\
India & $2.4 \mathrm{GW}$ \\
Germany & $2.4 \mathrm{GW}$ \\
Brazil & $1.1 \mathrm{GW}$ \\
USA & $830 \mathrm{MW}$ \\
France & $568 \mathrm{MW}$ \\
Turkey & $428 \mathrm{MW}$ \\
U.K. & $320 \mathrm{MW}$ \\
Sweden & $309 \mathrm{MW}$ \\
\hline
\end{tabular}

Since 1990, Germany has already adopted wind energy as its primary RE source [9], and tremendous savings in fossil fuel have been achieved. Germany is the largest wind market in Europe in 2015 with an installed capacity of 44,947 MW of which 70\% is offshore [3]. Wind energy contributes about $7.8 \%$ of Germany's net electricity consumption. In essence, wind power is the major contributor among the RE sources in Germany. Apart from Germany, Poland has the second largest market for wind power in Europe in 2015 with installed capacity of 13,603 MW, with $1266 \mathrm{MW}$ new installations by the end of 2015 [3]. Other countries in Europe like France and Turkey have also made tremendous progress regarding wind farm projects [3]. Turkey is another country with rapid growth in wind energy development. In Turkey, wind power potentials are estimated at $47 \mathrm{GW}$, and the installed wind capacity is forecasted to rise to 1000 MW per year [10]. Part of the RE plan of Turkey is to install up to $20 \mathrm{GW}$ of wind turbines by the year 2023 [11]. 
In comparison to the rest of the world, Africa possesses tremendous unexploited wind energy potentials. Recently, some African countries have already installed wind farms [12]. Currently, South Africa, Morocco, Egypt and Tunisia have the largest wind power capacity in the continent, $1053 \mathrm{MW}, 787 \mathrm{MW}, 610 \mathrm{MW}$ and $245 \mathrm{MW}$, respectively, at the end of 2015 [3,13]. Africa nowadays is at the bottom of the list of global installed wind power capacity [3]. Despite this progress in Africa's supply of wind energy, the total capacity of the wind installation in Africa accounts for about $0.4 \%$ of the world capacity [14], and this data reflect the need to further strengthen the growth of wind energy on the African continent. The weak growth of wind farms in Africa is due to the lack of clear policies in many countries. Besides, there is no detailed information available at project levels, which may hinder stakeholders and private individuals in understanding the market fully.

Among the developing countries, Cameroon and Nigeria are countries with abundant wind energy sources. In the case of Cameroon, the energy supplies from all sources are lower than the demand, and the country is heavily dependent on hydro-power [5], but this hydro-power is not readily available in all parts of the country. Hydro-power appears to be insufficient to supply the demand during the dry season, but wind power potentials seem to be at their peak during this period and can be seriously considered to supplement the hydro-power shortfalls [14]. The lack of stable RE policies over time, wind inclusive, are an obstacle to the development of the power system in Cameroon. Both Cameroon and Nigeria have power system infrastructure that is old and that needs to be upgraded to ensure proper functioning with the inclusion of future non-manageable renewable sources $[5,15,16]$. For the upgrade of the infrastructure, policies based on natural resources can be explored, such as subsidies from the exploitation of oil, among others [17,18]. The energy potential in Africa allows one not only to develop wind projects onshore, but also offshore $[19,20]$. Cameroon and Nigeria have large cities near the coasts, which could mean a development vector to drive offshore wind farm projects. This type of infrastructure has high costs compared to conventional projects onshore; however, it is necessary to consider them since the costs of investment and operation are becoming smaller $[18,21]$

On the other hand, a literature review [22-25] shows that a combination of energy sources (solar, wind, biomass and hydro) is one of the solutions to the current power crisis in Nigeria and can meet the electricity demand of the rural dwellers. Furthermore, the stability and coverage of supply in Nigeria could be improved. There exists an energy policy in Nigeria, but the implementation is going at a slow pace. For South Africa, wind power has already gathered steam, and it is currently one of the leading countries in Africa regarding renewable. Several wind farms have been installed and integrated into the grid.

This paper critically studies the current wind power development, policies and challenges in Cameroon and Nigeria and proposes the way forward. Specifically, lessons from South Africans' success in wind energy are discussed. The outline of the paper is as follows. Section 1 is the Introduction. Section 2 describes the current energy situation in Cameroon and Nigeria, while Section 3 evaluates the wind energy potentials in both countries, looking at their current and future installations. Then, Section 4 presents the energy policies in Cameroon and Nigeria before discussing the challenges in developing wind energy in those countries in Section 5. Afterwards, Section 6 reviews the wind energy resources and policies in South Africa before suggesting some lessons that can be learned for Cameroon and Nigeria in Section 7. Finally, Section 8 lays out the conclusions and the way forward for the two countries.

\section{Reality Check on Energy Situation in Cameroon and Nigeria}

\subsection{Geographical Locations}

Cameroon is located in central Africa, lies between latitudes $1^{\circ} \mathrm{N}$ and $13^{\circ} \mathrm{N}$ and longitudes $8^{\circ} \mathrm{E}$ and $17^{\circ} \mathrm{E}$ and has a total area of $475,440 \mathrm{~km}^{2}$ [26]. The population of Cameroon is 24.3 million [26] and is projected to grow by $2.58 \%$ per year [26]. As of 2016, Cameroon has a gross domestic product (GDP) 
of USD 77.2 billion with oil as its main export commodity, contributing up to $40 \%$ of the country's export earnings.

On the other hand, Nigeria is situated in West Africa and within latitude $4.32^{\circ} \mathrm{N}$ and $14^{\circ} \mathrm{N}$ and longitude $2.72^{\circ} \mathrm{E}$ and $14.64^{\circ} \mathrm{E}$ with a total area of $923,768 \mathrm{~km}^{2}$ [26]. As of 2014, it has a population of 186.1 million [26], which made it the most densely populated country in Africa [27]. Nigeria has become Africa's largest economy with the 2016 GDP estimated at USD 1.1 trillion. Its economy relies heavily on crude oil and natural gas, with a global ranking of Number 10 and Number 9, respectively, in terms of the proven reserved [26].

\subsection{Total Primary Energy Supply}

The total primary energy supply (TPES) in Cameroon shows a gradual rising trend, where the TPES increased by 50\% from 1990-2014, reaching close to 8 Mtoe [28]. Natural gas was introduced into the share of TPES in Cameroon from 2007, and its share was increasing every year [28]. As of 2014, biofuels and waste led the share with $64.41 \%$, followed by oil, natural gas and hydro at $22.54 \%, 7.31 \%$ and $5.73 \%$, respectively [28], as illustrated in Figure 3.

(a) Cameroon

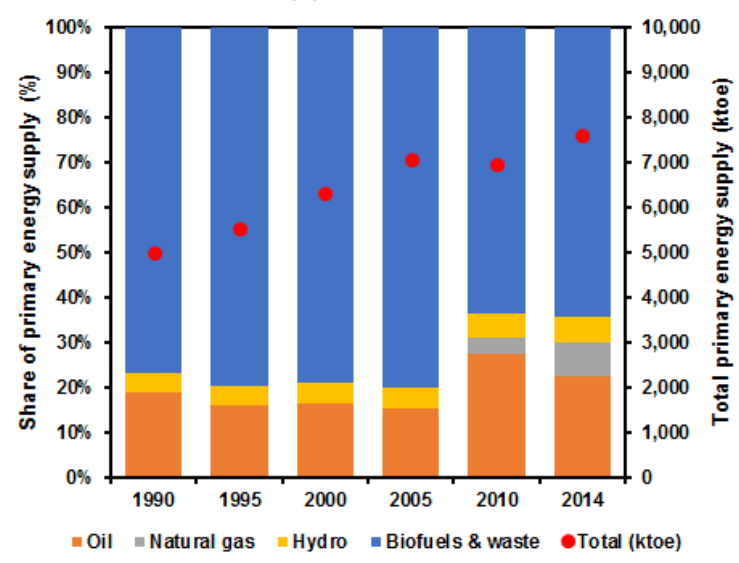

(b) Nigeria

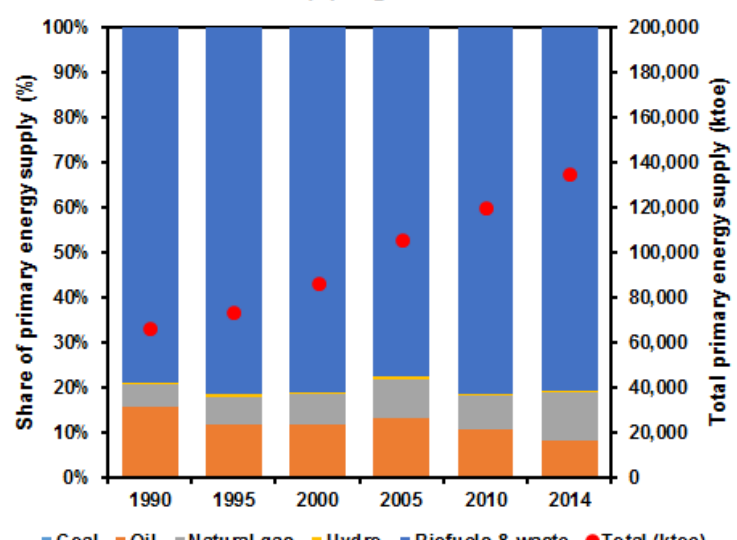

Figure 3. Total primary energy supply (in ktoe) for (a) Cameroon and (b) Nigeria in 2014. Adapted from [28].

\subsection{Electricity Sector}

Cameroon shows a rising trend in electricity generation, from 2697 GWh-6922 GWh in 2014, an increase by a factor of 2.6 [28]. Figure 4 shows the electricity generation in Cameroon from 1990-2014. The electricity generation in Cameroon was mainly from hydro at $73.2 \%$ followed by natural gas at $12.94 \%$, oil at $12.80 \%$ and biofuels and waste at $1.04 \%$ [28]. In fact, Cameroon possesses the second highest hydroelectric power stations after The Democratic Republic of Congo [29]. The contribution from oil and biofuels and waste was only started around a decade ago. In 2014, more than $50 \%$ of the electricity generated was consumed in industry sectors, followed by residential, commercial and public service and agriculture and forestry. The detailed breakdown of electricity consumption in the major sectors in Cameroon from 1990-2014 is tabulated in Table 2. 
Table 2. Electricity consumption (in GWh) in Cameroon from 1990-2014. Adapted from [28].

\begin{tabular}{ccccccc}
\hline Year & Industry & Residential & Commercial \& Public Service & Agriculture \& Forestry & Others & Total \\
\hline 1990 & 1359 & 317 & 273 & 0 & 396 & 2345 \\
1995 & 1279 & 289 & 250 & 0 & 360 & 2178 \\
2000 & 1516 & 387 & 334 & 0 & 481 & 718 \\
2005 & 1485 & 518 & 447 & 0 & 856 & 3306 \\
2010 & 2781 & 986 & 1036 & 60 & 0 & 4863 \\
2014 & 3011 & 1135 & 1261 & 78 & 0 & 5485 \\
\hline
\end{tabular}

Unfortunately, only $10 \%$ of the rural area and around $50 \%$ of the urban area have access to electricity in Cameroon [30]. As the population of Cameroon is expected to reach 32.9 million by 2030 [31], it is projected that the electricity demand in Cameron will reach 14.3 TWh by 2030 when calculated using an annual GDP projection of 6.1\% [32]. The government of Cameroon aims at introducing RE in meeting the future energy demand. Wind has the potential to contribute to satisfying the country's energy requirement [5].

Nigeria, on the other hand, showed a sharp rising trend, from 13,463 GWh in 1990 to 30,390 GWh in 2014 [28]. In the 1990s, oil and coal contributed up to $20 \%$ of the electricity production, but these sources were phased out, leaving only two major sources; natural gas at $82.4 \%$ and the remaining contributed by hydro (see Figure 4) [28]. Table 3 shows the electricity usage in various sectors in Nigeria from 1990-2014. As of 2014, more than half of the electricity generated in Nigeria was consumed in the residential sector, followed by commercial and public service and industry sectors [28].

(a) Cameroon

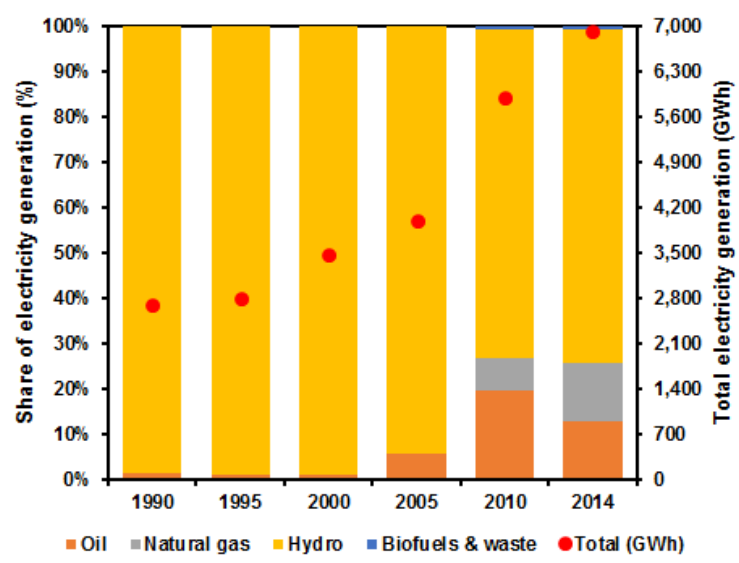

(b) Nigeria

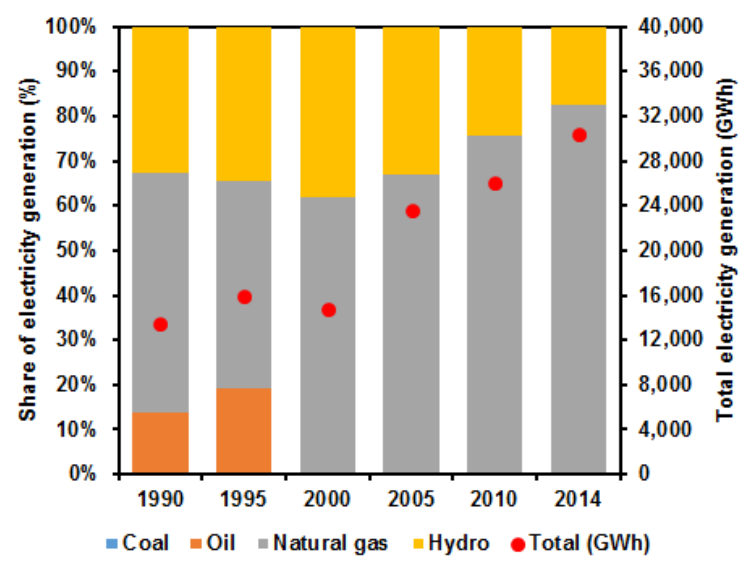

Figure 4. Total electricity generation (in GWh) for (a) Cameroon and (b) Nigeria in 2014. Adapted from [28].

Table 3. Electricity consumption (in GWh) in Nigeria from 1990-2014. Adapted from [28].

\begin{tabular}{ccccc}
\hline Year & Industry & Residential & Commercial \& Public Service & Total \\
\hline 1990 & 2016 & 3949 & 1906 & 7871 \\
1995 & 2037 & 4950 & 2449 & 9436 \\
2000 & 1866 & 4431 & 2346 & 8643 \\
2005 & 2119 & 10,302 & 4754 & 17,175 \\
2010 & 3249 & 11,962 & 5449 & 20,660 \\
2014 & 4057 & 14,003 & 6379 & 24,439 \\
\hline
\end{tabular}

It is interesting to note that around $40 \%$ of the population has access to the national electricity grid [33]; in fact, the net electricity generation per capita in Nigeria is among the lowest in the world [20,34]. To make matters worse, the grid suffers some problems around $60 \%$ of the time [35]. The most recent catastrophic event occurred in 2015 where 18 out of the 23 power plants in the country 
were shut down due to a shortage in the natural gas supply, as well as a water management issue at one of the hydro plants [36]. This causes many companies to resort to buying generators to continue their business activities during power blackouts. This expensive alternative adds an extra cost on to their operating expenditure [20]. As for residential households, many still rely on local biomass (e.g., wood, waste and charcoal) for heating and cooking.

The government of Nigeria aims at solving the continuous energy security and reliability issues. With the population expected to rise to 310 million by 2035 [34] and continuous expansion in its economy, the demand for electricity is also expected to rise. Bala [37] suggested that if the GDP growth is at $7 \%$ per annum, the electricity demand in Nigeria will reach $116 \mathrm{MW}$ by 2030 . In order to reduce the dependency on fossil fuels, RE is expected to play a part in meeting the future electricity need [38], in which wind is projected to supply roughly 54 MW by 2030 [37].

\section{Wind Energy Potentials, Current and Future Installations}

\subsection{Cameroon}

In most parts of Cameroon, the mean wind speed ranges between 2 and $5 \mathrm{~m} / \mathrm{s}$ at $10 \mathrm{~m}$ above ground. Several report assessments [39,40] shows that wind potentials in Cameroon exist in the western and northern parts of Cameroon, based on the data published by the meteorological department of the observation network [40,41]. These areas include Adamoua, Ngoundere, Garoua, Maroua, Bamenda, Ebolowa and Doula, as clearly shown in Figure 5.

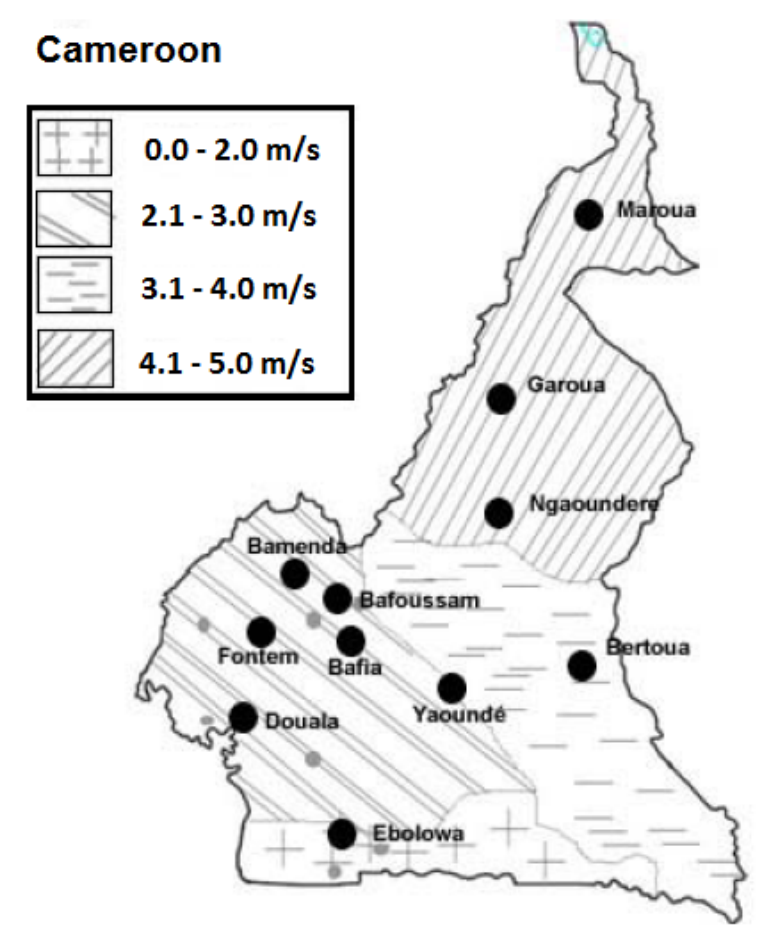

Figure 5. Map of Cameroon showing the mean monthly wind speed (10 m above height) [42].

Some investigations carried out on wind potentials in Cameroon are based on meteorological data from the National Meteorological Department of Cameroon. A study carried out by Afungchui et al. [14] shows that Bamenda area of Cameroon can be a suitable site for locating conventional horizontal wind turbines having a cut-off speed of $4 \mathrm{~m} / \mathrm{s}$. The same author evaluated the wind characteristics in Cameroon using the statistical Rayleigh distribution system [39]. The Rayleigh distribution applies the average wind speed as the input data. The Rayleigh together with the Weibull distribution were widely used for wind data analysis because of their accuracy in predicting the 
characteristics of the prevalent wind profile as presented in [43]. This distribution analysed the wind speed based on the following parameters: wind speed, velocity having the peak energy in the wind regime, wind power density, power available in the wind turbine, etc. The authors show that the three northern regions of Cameroon, namely Maroua, Garoua and Ngaoundore, are very fruitful for the installation of conventional horizontal axis wind turbines for power generation. Tchinda and Kaptouom [40] evaluated the wind energy potentials in north Cameroon and Adamaoua provinces. The northern area of Cameroon has an annual average wind speed of $2 \mathrm{~m} / \mathrm{s}$ over $55 \%$ of the time, while the Adamaoua region has a yearly average mean wind speed of $1 \mathrm{~m} / \mathrm{s}$ over $29 \%$ of the time. They proposed that it is possible to install alternatively windmills for supplying drinking water, household electricity and irrigation. These are essential needs in the regions mentioned above and would have positive impacts on communities.

Another study by Arreyndip et al. [44] evaluates the wind energy potential in Cameroon's coastal regions for the installation of the onshore wind farm. Three sites were selected, i.e., Kiribi, Doula and Limbe, and the wind characteristics of each site are presented in Table 4. Based on their analysis, they found that Kiribi is the most suitable site to install the wind farm, and the suggested wind turbine for this site would be the Savonius turbine.

Table 4. Wind characteristics for three sites in Cameroon for onshore wind farm installation [44].

\begin{tabular}{cccccccc}
\hline Data & Longitude & Latitude & $\begin{array}{c}\text { Height } \\
\mathbf{( m )}\end{array}$ & $\begin{array}{c}\text { Most Probable } \\
\text { Wind Speed, } \\
\text { Vmp (m/s) }\end{array}$ & $\begin{array}{c}\text { Maximum } \\
\text { Speed, } \\
\text { Vmax (m/s) }\end{array}$ & $\begin{array}{c}\text { Power } \\
\text { Density, } \\
\left.\text { PD (W/m } \mathbf{~} \mathbf{~}^{2}\right)\end{array}$ & $\begin{array}{c}\text { Maximum } \\
\text { Power, } \\
\left.\text { Pmax (W/m } \mathbf{~}^{2}\right)\end{array}$ \\
\hline Kribi & 9.98 & 2.88 & 15 & 2.426 & 3.35 & 33.7 & 160 \\
Doula & 9.7 & 4.05 & 41 & 1.67 & 2 & 8 & 30 \\
Limbe & 9.21 & 4.02 & 36 & 2.27 & 3.03 & 25.42 & 60 \\
\hline
\end{tabular}

Despite the high wind energy potentials in Cameroon, there is a noticeable lack of support by some agencies to implement some of the findings from the above studies. This is because of unclear RE policy stimulating the local and international players in the sector to play a part in the development of these regions. Currently, there are wind turbine installations in Douala hotel, Bafoussam Central Hotel, Bafou health clinic and M'mouck battery charging station (see Figure 6) $[45,46]$. These prove the viability and operation of small-scale projects to cover basic community needs.
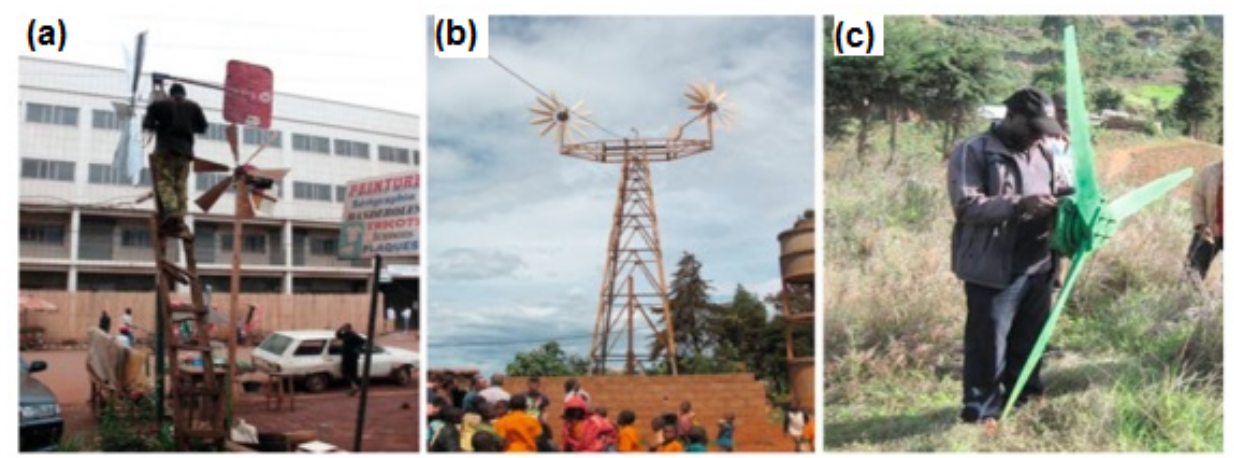

Figure 6. Wind turbines in some parts of Cameroon: (a) in Bafoussam; (b) in Bafou and (c) in M'muock [46].

Despite the slow progress in small wind projects in Cameroon, the Cameroonian government has identified wind energy as a source of the future energy mix of the country. Currently, a Spanish company (Ecovalen Energetica S.L.) is working towards establishing electricity generation wind turbines in Fundong, Boyo region in Cameroon. When accomplished, these turbines will provide adequate electric power to the whole area for about 20 years $[46,47]$. The project is an initiative of the 
Government of Cameroon and is expected to kick off in about a year's time [48]. The Cameroonian government chose this region as the target site for the project because of its high wind velocity. Apart from Boyo, similar projects are billed to take up in Manyu in the southwest of Cameroon and Mbouda in the western part of Cameroon [48]. In 2015, the Government of Cameroon launched a 42-MW wind farm in Mounts Bamboutos hills that would expand to $80 \mathrm{MW}$. This wind farm will complement and strengthen the energy mix source in Cameroon, which is currently dominated by hydroelectricity [48].

\subsection{Nigeria}

Over the years, several investigations have been carried out to determine wind energy potentials across Nigeria to identify areas suited for wind farms. The following authors $[24,25]$ have reported wind speed variations across Nigeria, while others evaluated the wind speed in some chosen areas of the country $[49,50]$. It is noteworthy that wind speed variation in Nigeria is quite similar to Cameroon. Wind speeds are found to be higher in some parts of northern Nigeria compared to the other part of the country (see Figure 7). Another investigation made by Ojosu and Salawu [24] reported that Sokoto area in the northern part of Nigeria possesses the highest average wind speed of about $5.12 \mathrm{~m} / \mathrm{s}$ annually.

Several authors [50-52] suggested that wind potentials in Nigeria are adequate for wind power integration to the national grid. The research carried out by the Energy Commission of Nigeria (ECN) [51] shows that it is possible to integrate wind farms at the distribution end of the national grid. Another study was reported by the African Development Bank (ADB) in 2004 [53], to evaluate the wind energy potential in 14 selected states in Nigeria. The study concluded that by just considering only $1 \%$ of land and a capacity factor of $30 \%$, an annual generation of more than 50 GWh could be achieved in those states, as demonstrated in Table 5. To date, there are no visible wind power projects connected to the grid. On top of that, currently in Nigeria, there is no sound policy that private institutions can rely on to enhance this sector.

Table 5. Wind energy potential in 14 selected states in Nigeria [53].

\begin{tabular}{|c|c|c|c|c|c|}
\hline State & $\begin{array}{l}\text { Land Area } \\
\left(\mathbf{k m}^{2}\right)\end{array}$ & $\begin{array}{l}\text { Percentage with Average Wind } \\
\text { Speed }>4 \mathrm{~m} / \mathrm{s}(\%)\end{array}$ & $\begin{array}{c}1 \% \text { of } \\
\text { Suitable Area } \\
\left(\mathrm{km}^{2}\right)\end{array}$ & $\begin{array}{c}\text { Installed } \\
\text { Capacity } \\
\text { (MW) }\end{array}$ & $\begin{array}{c}\text { Annual } \\
\text { Generation } \\
\text { (MWh) }\end{array}$ \\
\hline Adamawa & 37,957 & 45 & 170 & 854 & 2244 \\
\hline Bauchi & 48,197 & 50 & 240 & 1204 & 3166 \\
\hline Borno & 72,767 & 100 & 727 & 3638 & 9561 \\
\hline Gombe & 17,428 & 100 & 174 & 871 & 2290 \\
\hline Jigawa & 23,415 & 100 & 234 & 1170 & 3076 \\
\hline Kaduna & 44,217 & 60 & 265 & 1326 & 3486 \\
\hline Kano & 20,389 & 90 & 183 & 917 & 2411 \\
\hline Kebbi & 23,822 & 100 & 238 & 1191 & 3130 \\
\hline Katsina & 36,320 & 25 & 90 & 454 & 1193 \\
\hline Plateau & 26,539 & 90 & 238 & 1194 & 3318 \\
\hline Sokoto & 32,146 & 90 & 289 & 1446 & 3801 \\
\hline Taraba & 59,180 & 40 & 236 & 1183 & 3110 \\
\hline Yore & 44,880 & 100 & 448 & 2244 & 5897 \\
\hline Zamfara & 33,667 & 80 & 269 & 1346 & 3539 \\
\hline Total & & & 3808 & 19,043 & 50,046 \\
\hline
\end{tabular}




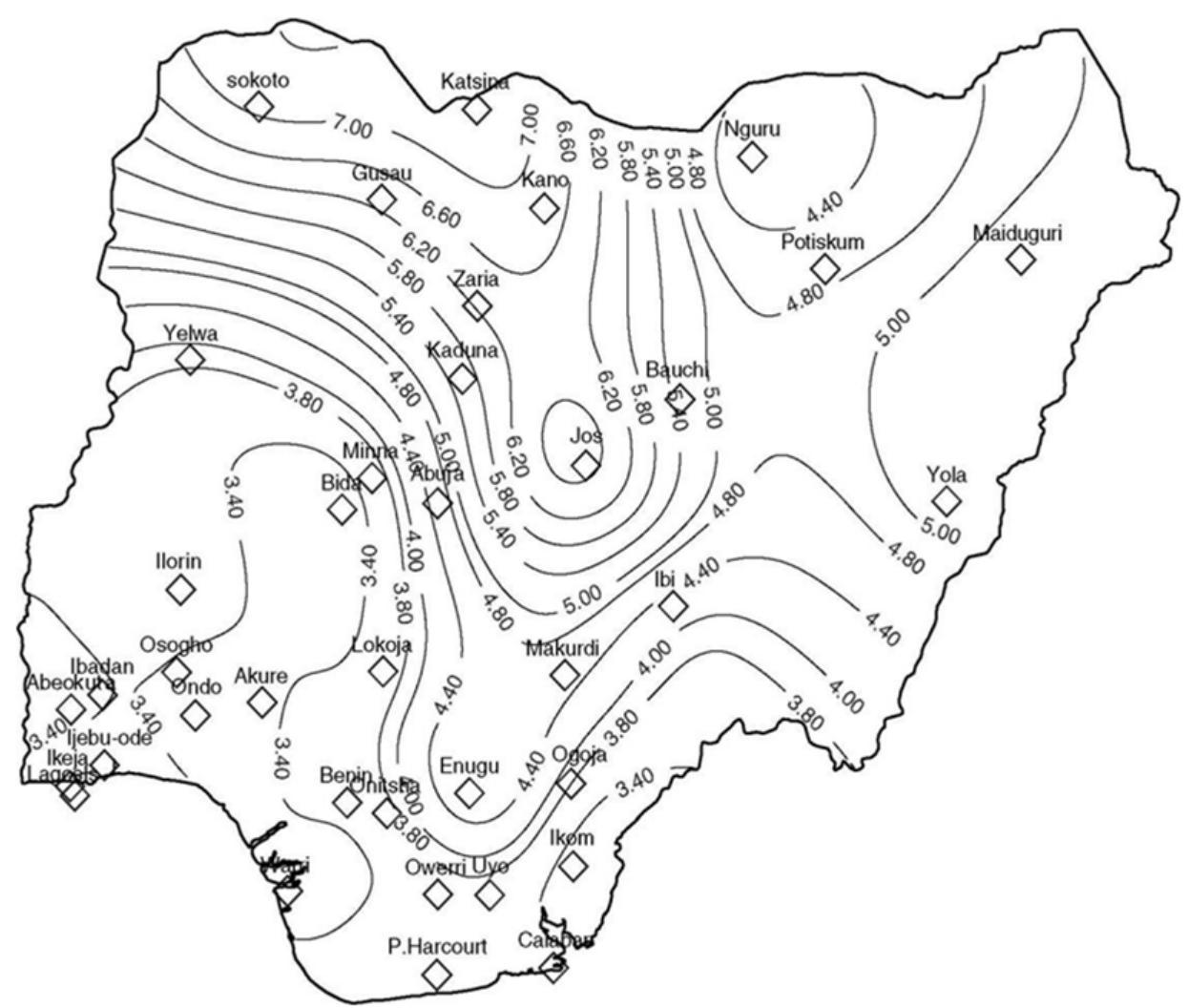

Figure 7. Map showing the average wind speed (in $\mathrm{m} / \mathrm{s}$ ) based on 40 years of measurements (1968-2007) at a $10 \mathrm{~m}$ height [38].

Over the years, the Sokoto Energy Research Centre (SERC) has made tremendous progress in developing some pilot wind energy projects, but they were restricted to rural electrification only. Some visible wind power projects across the country include a $10 \mathrm{~kW}$ power station at Danjawa village for supplying hybrid wind-photovoltaic system and a windmill dedicated to pumping water at Kadawa village in Kaduna state. There is also a $5 \mathrm{~kW}$ aero-generator in Sayya, Gidan Gada Sokoto (see Figure 8). Furthermore, there are several ongoing wind projects across Nigeria, which include the $10 \mathrm{MW}$ wind farm development in Katsina. This project has already been awarded by the Federal Government of Nigeria (FGN) since 2009 [54]. By 2015, the FGN announced that it had attained 98\% completion. Already, 37 wind turbines have been installed and tested [54]. The FGN has reiterated its commitment to ensure the smooth implementation of this project, and there is a plan to replicate the project over the entire northern part of Nigeria where the wind speed is high enough. The delay in completing the project is a result of the kidnapping of a French national in charge of the project, which forced the FGN to involve another company to finish the plan [54]. Currently, the FGN, through the Ministry of Science and Technology, has embarked on the development of an electronic wind map for wind speed assessment through the country $[55,56]$. The Usman Danfodio University, Sokoto, is currently developing two $215 \mathrm{~kW}$ wind turbines [55]. 

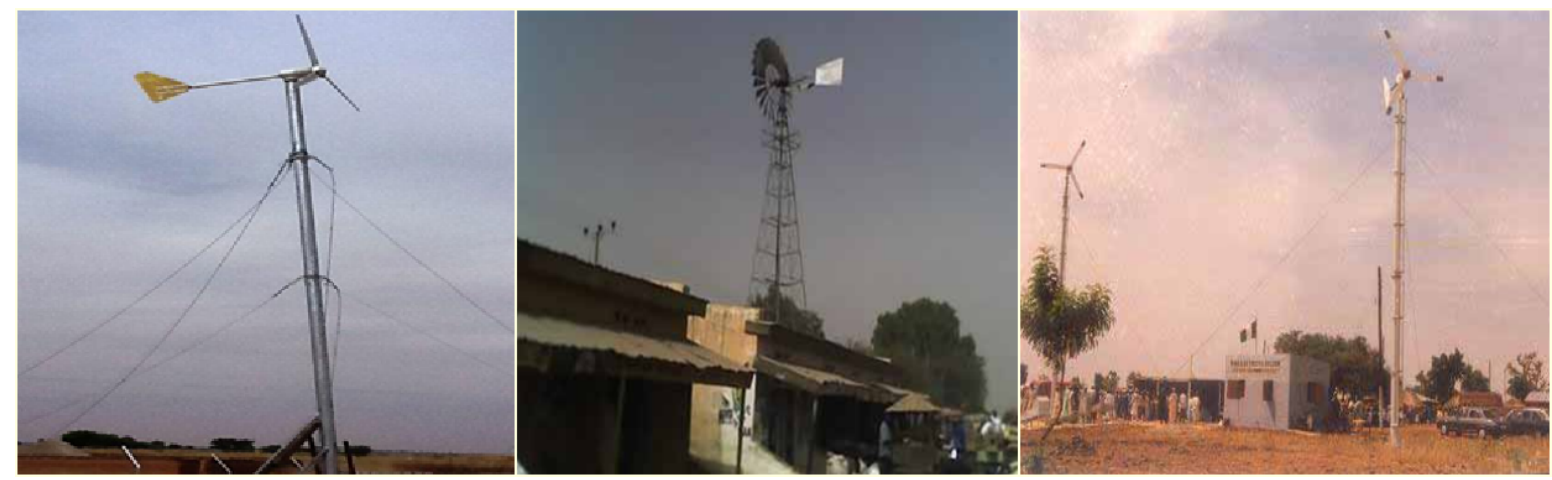

Figure 8. Wind turbines in some parts of Nigeria (from left to right): in Danjawa, in Kadawa and in Sayya, Gidan Gada $[55,56]$.

Several investigations have been carried out to show the suitable wind projects in different parts of Nigeria. An evaluation of wind energy availability for power generation in Kano city, Nigeria, has been carried out by Aidan [57], based on the performance characteristics of some suitable wind turbines, and is presented in Table 6.

Table 6. Wind power and wind availability for selected wind power [57].

\begin{tabular}{ccccccc}
\hline Turbine Type & V50 & Swept Area & \multicolumn{2}{c}{ Extractable Power } & \multicolumn{2}{c}{ Wind Availability } \\
\hline & $\mathbf{( m / s )}$ & $\mathbf{( m}^{2} \mathbf{)}$ & $\begin{array}{c}\text { Normal } \\
\mathbf{( k W )}\end{array}$ & $\begin{array}{c}\text { Weibull } \\
\mathbf{( k W )}\end{array}$ & $\begin{array}{c}\text { Normal } \\
\mathbf{( \% )}\end{array}$ & $\begin{array}{c}\text { Weibull } \\
\mathbf{( \% )}\end{array}$ \\
\hline Proven & 6.5 & 9.62 & 0.61 & 0.59 & 20.89 & 21.88 \\
Proven & 8 & 23.76 & 1.81 & 1.76 & 3.36 & 1.84 \\
Bergery & 8.94 & 38.49 & 3.88 & 3.78 & 2.48 & 1.14 \\
FL30 & 6.71 & 132.75 & 13.40 & 13.04 & 48.12 & 51.39 \\
FL100 & 8.05 & 346.41 & 40.74 & 39.65 & 19.66 & 20.42 \\
NW100 19 & 9.00 & 295.63 & 38.63 & 37.61 & 8.48 & 7.18 \\
Vestas27 & 10.24 & 572.63 & 67.34 & 65.54 & 0.41 & 0.04 \\
Vestas47 & 10.13 & 1735.17 & 287.15 & 279.50 & 6.85 & 3.30 \\
\hline
\end{tabular}

Aidan [57] proposed that the suitable wind turbine for Kano is Fuhrlander FL30 because $50 \%$ of its capacity can be extracted and can run for $50 \%$ of its operational time in a year. However, Aidan's conclusions have not been practically implemented and tested.

\subsection{Considerations for Future Installations}

In the context of Cameroon and Nigeria, the reliability of the interconnected system is not adequate. In non-interconnected areas, the situation is more complex and the supply less reliable. Self-consumption is an option that can help to solve the problems related to the continuity of supply and the coverage of zones by floor of the electrical system.

Several factors, such as wind turbulence, flickers in voltages and harmonics, are the likely issues that may affect the power system stability with RE penetration in those areas. There is currently no research work in the literature that has carried out this investigation. Power system stability issues depend on the RE integration level. The higher the penetration, the more likely the effect on the stability. In this case, measures can be taken to minimize these effects, such as using a power-limiting apparatus, load shedding, energy storage and smart metering.

Additionally, one solution to improve the power system stability with wind turbines, not only in the Nigerian situation, is by the use of the technique adopted by the literature, i.e., a combination of fixed (e.g., squirrel cage induction generator type) and variable wind turbines (i.e., doubly-fed 
induction generator). The variable wind turbines can help to achieve power stability during periods of transient and dynamic conditions associated with fixed wind turbines.

\section{Energy Policy}

\subsection{Cameroon}

There is no RE policy for Cameroon at the moment, but the plan remains drafted for the 2035 policy plans, which are under development. The lack of policy by the government is hindering other potential players from playing their part in developing the RE sector that is in abundance in the country $[5,46]$.

\subsection{Nigeria}

The Nigerian government has already developed a policy for wind energy utilization under the National Energy Master Plan. The policy states that the country shall promote its wind power resources for integration into a balanced energy mix. Necessary steps must be taken to harness this power at an affordable cost, especially to rural dwellers [58]. Specifically, the policy highlighted the following objectives:

1. Encouraging research and development in wind energy: The Nigerian government should embark on energy research and development activities by setting up research institutions relating to wind power research.

2. Developing skilled manpower to ensure local production of wind turbines and spare parts: the Cameroonian government shall build local capacity in the design and development of turbines, blades and power. The government shall establish linkages between institutions, research institutes and centres of excellence in wind energy technologies.

3. Intensifying efforts to ensure the acquisition and development of wind maps: the government shall establish more metrological centres for a regular acquisition of data relating to wind speed characteristics.

4. Training skilled local technicians for effective and efficient operation and maintenance of wind energy system. The government shall train experts on installations, utilization and maintenance of energy systems.

5. Providing appropriate incentives for developers and producers of wind power systems: The government shall provide fiscal incentives, such as suspension of import duty, tax holiday, investment grants, operational grants, etc., to encourage local production of wind energy systems.

6. Developing extension program to speed up the general application of wind energy technology: the government shall conduct public enlightenment through workshops, seminars and lectures. The government shall also design and sponsor any publicity through print and electronic media.

\subsection{Considerations to Perform Future Policies}

The feed-in-tariff is a policy that has worked well in developed countries in Europe, but cannot be raised in an uncontrolled way. Goals should be set and the costs of these policies estimated in a way that does not produce a deficit in the energy sector. With this policy, it is possible to promote the development of all types of projects, wind farms onshore and offshore, as well as solar plants.

\section{Challenges in Developing Wind Energy in Cameroon and Nigeria}

The identification of the challenges regarding wind energy improvement in Cameroon and Nigeria will permit actions to enhance the weight of wind power in these countries. One possible action is to look at another country with similar characteristics that have applied solutions for improving the growth of RE with good results, such as South Africa. South Africa shares socio-economic and cultural aspects with Cameroon and Nigeria, and therefore, this makes it possible to take it as similar; but most importantly, it leads the list of installed capacity and growth in wind power in Africa. 


\subsection{Cameroon}

Lack of RE (wind inclusive) policy has impaired the development of wind energy in Cameroon [59]. A financial system adapted for this type of project is needed, which facilitates the investment of the agents interested in developing wind energy projects. Furthermore, it is necessary to invest in research, both at local universities and research centres, to adapt technology and to close the technology gap that currently exists in Cameroon and Nigeria. It is necessary to build pilot plants at different scales, not only for research, but also for the training of local technical personnel. To carry out feasibility studies on wind, there is the need for an accurate database to estimate the wind energy potentials and the economic benefits from the sale of wind power.

\subsection{Nigeria}

Nigeria has already developed RE policy (wind energy inclusive). The ECN through the SERC has been empowered by the Nigerian government to carry out research and development related to wind energy. Several issues hinder the development of wind energy in Nigeria. These include inadequate funding for wind projects; lack of sufficient budget for research; specialized training of technical personnel is required; the current development is insignificant; and the lack of technical knowledge discourages the private sector from investing in new projects [55].

\section{Wind Energy Resources and Policies in South Africa}

South Africa, a developing country in Africa, gained its independence as a republic in 1961, about the same time as Cameroon and Nigeria. However, South Africa is considered to be among the African countries that are progressing well in RE, specifically in the development of wind for power generation [3]. The wind speed in South Africa is estimated to be between $7.2 \mathrm{~m} / \mathrm{s}$ and $9.7 \mathrm{~m} / \mathrm{s}$ around Cape Agulhas and Cape Point [60], which is slightly higher than Cameroon and Nigeria. The wind energy potentials in South Africa are estimated to be 26,000 GWh annually [61]. South Africa has promising wind resources, as can be seen in Figure 9 [62]. The greatest wind energy potentials are in the coastal zones and the tops of the mountain ranges.

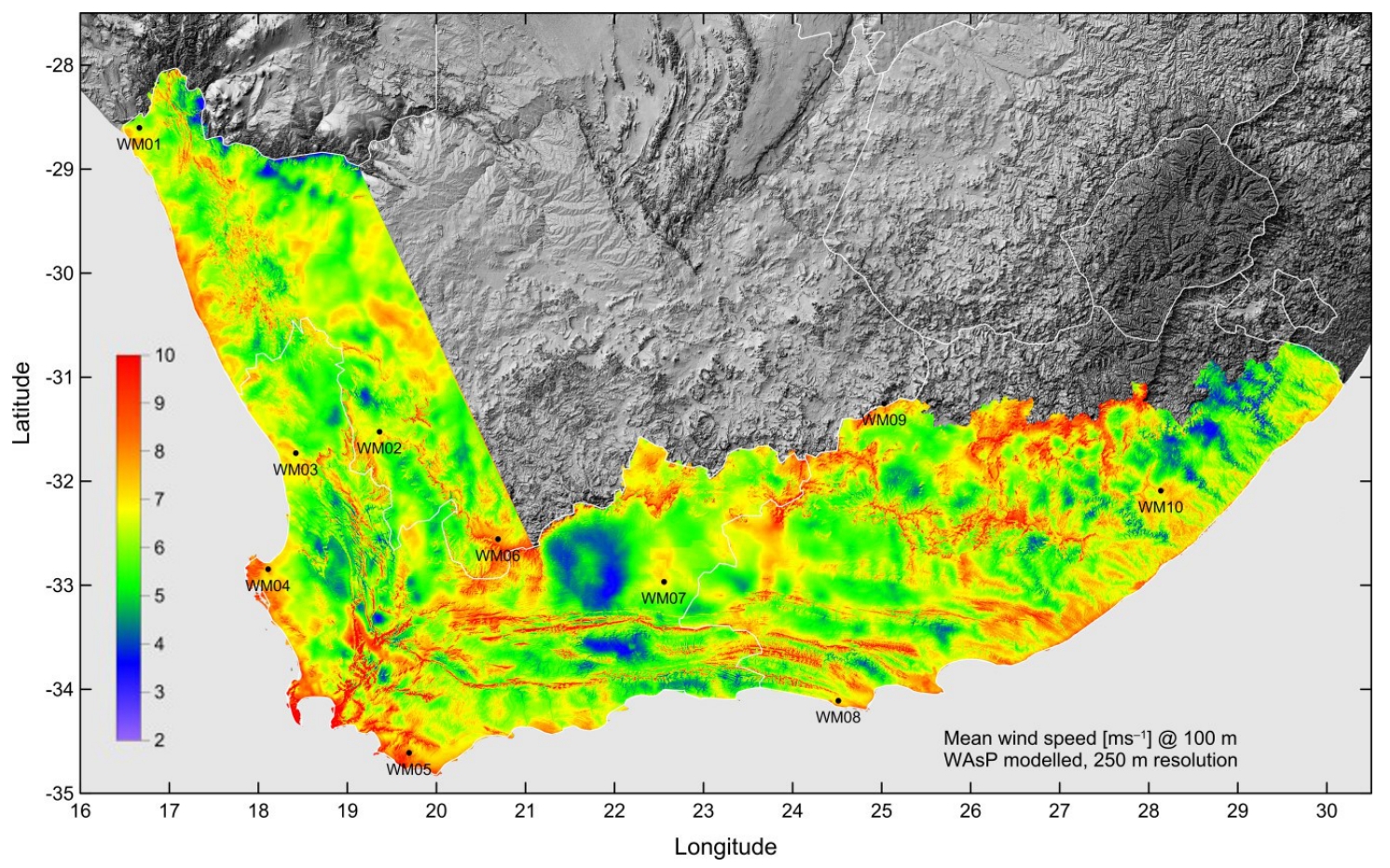

Figure 9. Wind map developed by Wind Atlas for South Africa (WASA) [62]. 
In 2015, a total of $483 \mathrm{MW}$ of wind power was added to South Africa electricity grid, bringing the cumulative capacity to 1053 MW. During 2016, there was a considerable development, where several large wind farms are now fully operational, and much more are under construction. The development of South Africa's wind industry and market has taken place in the last four years, being a relatively short period compared with other countries. Nowadays, South Africa is at the top list of wind markets globally; this development is beneficial in strengthening the industry and its supply chain [3].

The Integrated Resource Plan of South Africa has a goal to develop 9 GW of wind power by 2030 [63]. However, the South African Wind Energy Association expects this figure to rise by a wide margin and about $15 \mathrm{GW}$ of projects to be installed by 2030. The development of wind technologies that are necessary, like RE, is a good source of new power that can be deployed quickly enough to solve South Africa's needs and goals. Small sized solutions have advantages associated with their ease of construction and short time periods for installation. Wind farms, for instance, can take less than a year to build. The size of renewable plants allows a gradual growth that can match more precisely the increase in demand [3].

The Government of South Africa has already adopted policies, acts, strategies and task teams for the development of RE. Since 1998, the Government of South Africa believes that renewable can provide savings in energy with consideration of social, economic and environmental cost. This led to the development of the White Paper of 1998 [64]. The White Paper particularly mentioned that the government would place immediate emphasis on programs such as biomass applications, photovoltaic (PV), passive building design, micro-hydro, wind-based electricity systems and solar water heating. The objective of the 1998 White Paper is as follows [64]:

- Improve access to energy services.

- Improve the governance of the energy in the context of transparency and accountability.

- Encouragement of economic development.

- Effectively manage environmental and health effects of energy.

- Secure the power supply through diversity.

Afterwards, the 2003 White Paper was released [65], where the South African government clearly stated that to meet its long-term objectives for a sustainable energy industry, a ten-year target plan must be set up. The RE should contribute about 10,000 GWh to the final energy consumption by 2013, which must be from the wind, solar, biomass and small-scale hydro. By the end of 2003, the Integrated Energy Plan (IEP) was made public. This plan developed an approach of taking actions related to energy policy and to efficiently enhance the energy sources and their technologies in the country. The IEP was developed based on the energy demand and consumption up to the year 2020 by considering the different economic scenarios for South Africa $[65,66]$.

In late 2005, the South African government established the Renewable Energy Finance and Subsidy Office. The Office's responsibilities include the management of RE subsidies and providing advice to other stakeholders and developers on RE finance and subsidies, including the size of awards, eligibility and procedural requirements. Table 7 shows the summary of the energy policy and actions related to RE in South Africa. 
Table 7. The summary of the policies and purposes related to RE in South Africa [67].

\begin{tabular}{|c|c|c|}
\hline Policy & Purpose & Introduction \\
\hline $\begin{array}{l}\text { White paper on } \\
\text { energy policy. }\end{array}$ & $\begin{array}{l}\text { The general energy policy, setting the goal of } \\
\text { developing RE by fiscal reform, legislative and } \\
\text { regulatory regimes. }\end{array}$ & $\begin{array}{l}1998 \text { and renewed } \\
\text { in } 2009\end{array}$ \\
\hline White paper on RE. & $\begin{array}{l}\text { Laying the foundation for RE implementation and } \\
\text { targeting 10,000 GWh by } 2013 \text {. }\end{array}$ & 2003 \\
\hline $\begin{array}{l}\text { National cleaner } \\
\text { production strategy. }\end{array}$ & $\begin{array}{l}\text { Promoting sustainable energy production and } \\
\text { consumption across industries in South Africa. }\end{array}$ & 2004 \\
\hline Energy Act. & $\begin{array}{l}\text { Strategy for increasing generation and consumption } \\
\text { planning of RE and other sources. }\end{array}$ & 2009 \\
\hline RE feed-in-tariff program. & $\begin{array}{l}\text { Set tariff for wind, small hydro, concentrated solar } \\
\text { and landfill gas technologies. }\end{array}$ & 2011 \\
\hline Integrated resource plan. & $\begin{array}{l}\text { A national long-term plan on electricity supply } \\
\text { based on nuclear power coal and renewable } \\
\text { energies. Total PV capacity cost is } 8400 \mathrm{MW} \text {. }\end{array}$ & 2010-2030 \\
\hline RE bids. & $\begin{array}{l}\text { Independent power producers bid for on-grid } \\
\text { production capacity. In the first round (2012), } \\
1415 \text { MW was allocated across concentrated solar } \\
\text { PV and bio-gas. }\end{array}$ & 2011 \\
\hline
\end{tabular}

\section{Lessons for Cameroon and Nigeria}

There are some lessons from South Africa that could be learned by the Cameroonian and Nigerian governments, specifically in terms of increasing wind power penetration in these countries. These include:

1. The establishment of the Renewable Energy Independent Power Plant Procurement Program (REIPPPP), which provides the platform for the government and the private sector to be committed to developing the RE program, especially wind energy [68,69]. REIPPPP in South Africa is successful due to banking, legal and other resources that many countries in the continent do not possess. Therefore, the government and private sector commitment is one of the key factor in the success of RE, and both Cameroon and Nigeria can learn from the South African experience.

2. Establish funding from donors and development financial institutions (DFIs). Funding from donors and DFIs can help develop RE in many areas, especially on issues of supplying advisors, project preparation, cost reduction of projects and partial risk guarantees, which could be helpful for a government with below investment-grade credit rating [69]. Other developing countries like Cameroon and Nigeria should explore the possibility of getting support from donors and DFIs.

3. Establish quality procurement and contracting documentation and processes in place. There is a need for a competitive tender or effective procurement mechanism in place to ensure bankable power purchases, implementation agreements and also appropriate credit enhancement or security arrangement that make the project bankable. Cameroon and Nigeria should establish an effective procurement, contracting and implementation framework to help them avoid a situation whereby projects fail or close.

4. Establishment of RE feed-in-tariff: In 2008, South Africa initiated a process to establish RE feed-in-tariff (REFIT) in order to accelerate the feeding of RE supply sources into the national grid. In 2009, the National Energy Regulator of South Africa (NERSA) introduced the REFIT and made it public. This proposed REFIT covers the power generating costs and after tax return of $17 \%$ tax equity [70]. The REFIT was set at 10.4 cents $/ \mathrm{kWh}$ (1.25 R) [71]. However, considerations should be made, such as gradual reductions in time or fixing an amount of installed power to finance. These measures were very successful in European countries, such as Germany, Denmark and Spain, among others [72,73]. 


\section{Conclusions}

This paper has evaluated the wind energy potentials in Cameroon, Nigeria and South Africa. Among them, in Cameroon, there is heavy dependence on hydro-power, which is not readily available in all parts of the country, especially in the dry season. During this season, wind has the capability to complement hydro in generating electricity because its potential is at the peak. Presently, there is a lack of clear RE policy in Cameroon that can accelerate the development of wind as an alternative source of electricity in the country. Several organizations have attempted to install wind turbines in some parts of the country, but to date, have produced no progress. Lack of maintenance and commitment from the Cameroonian policy makers has hindered the process. In Cameroon, there is a need for clear wind energy policy that covers certain aspects of research, manpower development and encouraging extension programs that can facilitate the general application of wind power technology. The Cameroonian government shall be fully involved in carrying out feasibility studies for the implementation of wind turbines especially in rural areas with no access to electricity. There is also a need for the Cameroonian government to critically assess the integration of wind farms into the national grid and possible wind farms sites. The Cameroonian government should carry out sponsored research on the voltage and reliability studies on wind power in several parts of the country to be aware of any consequences on the power system as a result of the wind integration.

For Nigeria, the country is yet to have a working wind farm despite vast wind potentials. In Nigeria, there is a clear policy available to the public, but its implementation is slow. Though Nigeria has set up research and development centres for wind energy, there are some challenges, which include inadequate funding from the government, manpower training and development and lack of awareness by entrepreneurs to develop this sector. Currently, there are a few wind turbines installed in some parts of Nigeria, but its application is limited to water pumping and small-scale electricity generation.

South Africa has already made tremendous progress regarding RE especially in the wind sector, from which Cameroon and Nigeria can learn. Several wind farms have been commissioned and integrated into the grid on a large scale. South Africa already has a policy on RE. Since 1998, two white papers were developed and are available to the public. The two white papers have already attracted both local and direct foreign investments into the sector. Local manufacturing of wind turbines is becoming competitive. The lessons to be learned from South Africa's wind energy progress are:

- Establishment of REIPPPP to provide the platform for the government and the private sector to be committed to developing the RE program, especially wind energy;

- $\quad$ Establish funding from donors and DFIs;

- Create quality procurement and contracting documentation and processes in place;

- Establishment of REFIT.

Acknowledgments: The authors acknowledge the support of the Chilean Research Council (CONICYT), under the project Fondecyt 11160115.

Author Contributions: Abdullahi Abubakar Mas'ud and Asane Vernguy Wirba wrote the review paper and provided the analysis of the results. Firdaus Muhammad-Sukki, Ricardo Albarracín and Jorge Alfredo Ardila-Rey helped in the analysis of the review results and provided suggestions for improvement. Álvaro Jaramillo Duque extensively reviewed the paper and updated the document based on recent data. Nurul Aini Bani and Abu Bakar Munir carried out a proofreading of the article and provided suggestions for improvement.

Conflicts of Interest: The authors declare no conflict of interest.

\section{References}

1. Mostafaeipour, A.; Jadidi, M.; Mohammadi, K.; Sedaghat, A. An analysis of wind energy potential and economic evaluation in Zahedan, Iran. Renew.d Sustain. Energy Rev. 2014, 30, 641-650.

2. REN21. Renewables 2016 Global Status Report; Technical Report; Renewable Energy Policy Network (REN21): Paris, France, 2016. 
3. Global Wind Energy Council (GWEC). Global Wind Statistics 2015; Technical Report; Global Wind Energy Council (GWEC): Brussels, Belgium, 2016.

4. Joselin Herbert, G.M.; Iniyan, S.; Amutha, D. A review of technical issues on the development of wind farms. Renew. Sustain. Energy Rev. 2014, 32, 619-641.

5. Wirba, A.V.; Abubakar Mas'ud, A.; Muhammad-Sukki, F.; Ahmad, S.; Mat Tahar, R.; Abdul Rahim, R.; Munir, A.B.; Karim, M.E. Renewable energy potentials in Cameroon: Prospects and challenges. Renew. Energy 2015, 76, 560-565.

6. REN21. Renewables 2015 Global Status Report; Technical Report; Renewable Energy Policy Network (REN21): Paris, France, 2015.

7. World Wind Energy Association (WWEA). WWEA Half-Year Report; Technical Report; World Wind Energy Association (WWEA): Bonn, Germany, 2016.

8. Mukasa, A.D.; Mutambatsere, E.; Arvanitis, Y.; Triki, T. Development of Wind Turbine in Africa; Technical Report 170; African Development Bank Group: Centurion, South Africa, 2013.

9. Weigt, H. Germany's wind energy: The potential for fossil capacity replacement and cost saving. Appl. Energy 2009, 86, 1857-1863.

10. Eskin, N.; Artar, H.; Tolun, S. Wind energy potential of Gökçeada Island in Turkey. Renew. Sustain. Energy Rev. 2008, 12, 839-851.

11. Başoğlu, M.E.; Çakir, B. Wind energy status in Turkey. WASET Int. J. Environ. Chem. Ecol. Geol. Geophys. Eng. 2015, 9, 19-24.

12. Mentis, D. Wind Energy Assessment in Africa; A GIS-Based Approach. Master's Thesis, Royal Institute of Technology (KTH), School of Industrial Engineering and Management (ITM), Stockholm, Sweden, 2013.

13. Riahi, L.; Zissler, R.; Lins, C.; Bryden, J.; Bida, A.; Mahmoud, M.; Erdle, S.; Ferroukhi, R.; Lavagne, O.; Goldiescot, L.; et al. Middle East News Agency Renewables Status Report; INIS Repository: Paris, France, 2013.

14. Afungchui, D.; Aban, C.E. Analysis of wind regimes for energy estimation in Bamenda, of the North West Region of Cameroon, based on the Weibull distribution. Revue des Energies Renouvelables 2014, 17, 137-147.

15. Folorunso, O.; Olowu, T. The Nigerian Power System Till Date: A Review. Int. J. Adv. Found. Res. Sci. Eng. 2014, 1, 20-33.

16. Kidmo, D.K.; Deli, K.; Raidandi, D.; Yamigno, S.D. Wind Energy for Electricity Generation in the Far North Region of Cameroon. Energy Procedia 2016, 93, 66-73.

17. Oniemola, P.K. Why Should Oil Rich Nigeria Make A Law for the Promotion of Renewable Energy in the Power Sector J. Afr. Law 2016, 60, 29-55.

18. Okafor, E.N.C.; Joe-Uzuegbu, C.K.A. Challenges to development of renewable energy for electric power sector in Nigeria. Int. J. Acad. Res. 2010, 2, 211-216.

19. Mentis, D.; Hermann, S.; Howells, M.; Welsch, M.; Siyal, S.H. Assessing the technical wind energy potential in Africa a GIS-based approach. Renew. Energy 2015, 83, 110-125.

20. Mas'ud, A.A.; Vernyuy Wirba, A.; Muhammad-Sukki, F.; Mas'ud, I.A.; Munir, A.B.; Md Yunus, N. An assessment of renewable energy readiness in Africa: Case study of Nigeria and Cameroon. Renew. Sustain. Energy Rev. 2015, 51, 775-784.

21. Effiom, S.O.; Nwankwojike, B.N.; Abam, F.I. Economic cost evaluation on the viability of offshore wind turbine farms in Nigeria. Energy Rep. 2016, 2, 48-53.

22. Agbetuyi, A.F.; Akinbulire, T.; Abdulkareem, A.; Awosope, C.O.A. Wind energy potential in Nigeria. Int. Electr. Eng. J. 2012, 3, 595-601.

23. Ajayi, O.O.; Fagbenle, R.O.; Katende, J.; Ndambuki, J.M.; Omole, D.O.; Badejo, A.A. Wind Energy Study and Energy Cost of Wind Electricity Generation in Nigeria: Past and Recent Results and a Case Study for South West Nigeria. Energies 2014, 7, 8508-8534.

24. Ojosu, J.O.; Salawu, R.I. A survey of wind energy potential in Nigeria. Sol. Wind Technol. 1990, 7, $155-167$.

25. Adekoya, L.O.; Adewale, A.A. Wind energy potential of Nigeria. Renew. Energy 1992, 2, 35-39.

26. CIA. World Fact Book. 2017. Available online: https://www.cia.gov/library/publications/ the-world-factbook/ (accessed on 19 January 2017)

27. Shaaban, M.; Petinrin, J. Renewable energy potentials in Nigeria: Meeting rural energy needs. Renew. Sustain. Energy Rev. 2014, 29, 72-84.

28. IEA. Statistics. Available online: https://www.iea.org/statistics/statisticssearch/ (accessed on 13 February 2017). 
29. Tchouaha, S. Hydropower in Cameroon. Bachelor's Thesis, University of Gavle, Gävle, Sweden, 2012.

30. Mboumboue, E.; Njomo, D. Potential contribution of renewables to the improvement of living conditions of poor rural households in developing countries: Cameroon's case study. Renew. Sustain. Energy Rev. 2016, 61, 266-279.

31. UN. World Population Prospects: The 2015 Revision, Key Findings and Advance Tables; Department of Economic and Social Affairs: New York, NY, USA, 2015.

32. Dountio, E.G.; Meukam, P.; Tchaptchet, D.L.P.; Ango, L.E.O.; Simo, A. Electricity generation technology options under the greenhouse gases mitigation scenario: Case study of Cameroon. Energy Strateg. Rev. 2016, 13-14, 191-211.

33. Somefun, O.A. The Erratic Electric Power Supply in Nigeria: Causes and Remedy; Technical Report; The Department of Electrical and Electronics Engineering, Federal University of Technology: Akure, Nigeria, 2015.

34. Ley, K.J.G.; Ghatikar, A. The Nigerian Energy Sector-an Overview With A Special Emphasis on Renewable Energy, Energy Efficiency and Rural Electrification; GOPA International Consultants GmbH: Bad Homburg vor der Höhe, Germany, 2014.

35. Aliyu, A.S.; Ramli, A.T.; Saleh, M.A. Nigeria electricity crisis: Power generation capacity expansion and environmental ramifications. Energy 2013, 61, 354-367.

36. Udo, B. Nigeria's Energy Crisis Worsens, Only 5 of 23 Power Plants Functional-NERC; Nigerian Electricity Regulatory Commission (NERC)—The Premium Times Nigeria: Abuja, Nigeria, 2015.

37. Bala, E.J. Electricity Demand and Supply Projections to 2030. In Proceedings of the Presidential Task Force on Power-MDA Power Sector Pre-Conference, Abuja, Nigeria, 6 February 2013.

38. Aliyu, A.S.; Dada, J.O.; Adam, I.K. Current status and future prospects of renewable energy in Nigeria. Renew. Sustain. Energy Rev. 2015, 48, 336-346.

39. Afungchui, D. Rayleigh distribution-based model for prediction of wind energy potential in Cameroon. Energy Rev. 2014, pp. 26-43.

40. Tchinda, R.; Kaptouom, E. Wind energy in Adamaoua and North Cameroon provinces. Energy Convers. Manag. 2003, 44, 845-857.

41. Tchinda, R.; Kendjio, J.; Kaptouom, E.; Njomo, D. Estimation of mean wind energy available in far north Cameroon. Energy Convers. Manag. 2000, 41, 1917-1929.

42. Tansi, B.N. An Assessment of Cameroon's Renewable Energy Resource Potential and Prospects for A Sustainable Economic Development. Master's Thesis, Brandenburg University of Technology, Cottbus, Germany, 2011.

43. Pishgar-Komleh, S.H.; Keyhani, A.; Sefeedpari, P. Wind speed and power density analysis based on Weibull and Rayleigh distributions (a case study: Firouzkooh county of Iran). Renew. Sustain. Energy Rev. 2015, 42, 313-322.

44. Arreyndip, N.A.; Joseph, E.; David, A. Wind energy potential assessment of Cameroon's coastal regions for the installation of an onshore wind farm. Heliyon 2016, 2, e00187.

45. Nfah, E.M.; Ngundam, J.M. Identification of stakeholders for sustainable renewable energy applications in Cameroon. Renew. Sustain. Energy Rev. 2012, 16, 4661-4666.

46. Fonchingong, T.N.; Gemandze, J.B. Cameroon: The Stakes and Challenges of Governance and Development; African Books Collective: Oxford, UK, 2009.

47. Ministry of Justice. Report by the Ministry of Justice on Human Rights in Cameroon in 2009; Ministry of Justice on Human Rights: Yaoundé, Cameroon, 2010.

48. Cameroon Mirror. Cameroon Announces a First-Time Trial Run at the $42 \mathrm{MW}$ Windpower Plant in the Monts Bamboutos Hills, 2015. Available online: http://cameroonmirror.com/2015/05/ (accessed on 10 January 2017).

49. Anyanwu, E.E.; Iwuagwu, C.J. Wind characteristics and energy potentials for Owerri, Nigeria. Renew. Energy 1995, 6, 125-128.

50. Medugu, D.W.; Malgwi, D.I. A study of wind energy potential: Remedy for fluctuation of electric power in Mubi, Adamawa State, Nigeria. Niger. J. Phys. 2005, 17, 40-45.

51. Sambo, A.S. Strategic developments in renewable energy in Nigeria. Int. Assoc. Energy Econ. 2009, 16, 15-19. 
52. Okoro, O.I.; Chikuni, E.; Govender, P. Prospect of wind energy in Nigeria. In Proceedings of the International Conference on Domestic Use of Energy, Cape Town, South Africa, 10-13 April 2007.

53. Dvorak, I.E.; Cervigni, R.E.; Rogers, J.A.E.; Kaenzig, R. Assessing Low-Carbon Development in Nigeria: An Analysis of Four Sectors; Technical Report 78281; The World Bank: Washington, DC, USA, 2013.

54. Afungchui, D. Renewable Energy Policy and Plans in Nigeria; Federal Government of Nigeria (FGN): Abuja, Nigeria, 2011.

55. Usmanu Danfodiyo University. Sokoto Energy Research Centre, 2015. Available online: https://www. udusok.edu.ng/ (accessed on 1 March 2015).

56. Sambo, A.S. Renewable energy development in Nigeria. In Proceedings of the the World's Future Council and Strategy Workshop on Renewable Energy, Accra, Ghana, 21-24 June 2010.

57. Aidan, J. An Assessment of Wind Availability for Turbine Power Generation in Kano, Nigeria. J. Appl. Phys. 2016, 6, 30-36.

58. National Master Plan-Final Draft. Energy Comission of Nigeria; NAEC: Abuja, Nigeria, 2007.

59. Walwyn, D.R.; Brent, A.C. Renewable energy gathers steam in South Africa. Renew. Sustain. Energy Rev. 2015, 41, 390-401.

60. Ayodele, T.R.; Jimoh, A.A.; Munda, J.L.; Agee, J.T. Wind distribution and capacity factor estimation for wind turbines in the coastal region of South Africa. Energy Convers. Manag. 2012, 64, 614-625.

61. Pegels, A. Renewable energy in South Africa: Potentials, barriers and options for support. Energy Policy 2010, 38, 4945-4954.

62. Wind Atlas for South Africa. Wind Atlas for South Africa (WASA) SANEDI; WASA: Sandton, South Africa, 2017.

63. Department of Energy. Integrated Resource Plan, Department of Energy, Republic of South Africa; Department of Energy: Washington, DC, USA, 2016.

64. Department of Minerals and Energy. White Paper on the Energy Policy of the Republic of South Africa; Department of Minerals and Energy: Pretoria, South Africa, 1998.

65. Department of Minerals and Energy. White Paper on Renewable Energy; Department of Minerals and Energy: Washington, DC, USA, 2003.

66. Chaker, A.; El-Fadl, K.; Chamas, L.; Hatjian, B. A review of strategic environmental assessment in 12 selected countries. Environ. Impact Assess. Rev. 2006, 26, 15-56.

67. Votteler, R.G.; Brent, A.C. A literature review on the potential of renewable electricity sources for mining operations in South Africa. J. Energy S. Afr. 2016, 27, 1-21.

68. Anton, E.; Joel, K.; James, L. South Africa's Renewable Energy IPP Procurement Program; World Bank Publications: Washington, DC, USA, 2014.

69. Eberhard, A.; Kolker, J.L.J. Africa's Renewable Energy IPP Procurement Program: Success Factors and Lessons; Public-Private Infrastructure Advisory Facility: Nairobi, Kenya, 2014.

70. Department of Energy. State of Renewable Energy in South Africa; Department of Energy: Pretoria, South Africa, 2015.

71. Mendonca, M.; Jacobs, D.; Sovacool, B.K. Powering the Green Economy: The Feed-in Tariff Handbook; Earthscan: London, UK, 2009.

72. Munksgaard, J.; Morthorst, P.E. Wind power in the Danish liberalised power market-Policy measures, price impact and investor incentives. Energy Policy 2008, 36, 3940-3947.

73. García-Alvarez, M.T.; Mariz-Pérez, R.M. Analysis of the Success of Feed-in Tariff for Renewable Energy Promotion Mechanism in the EU: Lessons from Germany and Spain. Procedia-Soc. Behav. Sci. 2012, 65, 52-57.

(C) 2016 by the authors. Licensee MDPI, Basel, Switzerland. This article is an open access article distributed under the terms and conditions of the Creative Commons Attribution (CC-BY) license (http:/ / creativecommons.org/licenses/by/4.0/). 